\title{
Climate Justice and Human Rights
}

\begin{abstract}
Climate change as well as climate policies can have adverse effects on the human rights of certain population groups - and can exacerbate situations of injustice. As it stands today, the human rights regime is not set to sufficiently address these situations of climate injustice. In this article, I suggest a systematization of the normative climate justice literature that can be used as an analytical framework to evaluate current developments in human rights law and policy, and their potential to diminish inter-national, intra-societal and intergenerational climate injustice. I argue that further advancing procedural and substantive human rights obligations and corresponding enforcement mechanisms constitute one important way of establishing climate justice practices. Moreover, I suggest that the normative climate justice literature can be fruitfully used in International Relations to evaluate policy developments at the intersection between climate change and other policy fields.
\end{abstract}

"The law - human rights law [...] - is not ready-made to deliver climate justice: it must evolve. A question that arises is whether it can."

1

\section{Introduction}

In the face of anthropogenic climate change, we have begun to re-think justice. New reflections on the temporal and spatial aspects of justice have gained meaning. ${ }^{2}$ It becomes increasingly relevant to consider how just relations between state actors, societies and generations in the context of climate challenges can be construed. Who bears the responsibility for and who are the "recipients ${ }^{3}$ of climate justice? What obligations does climate justice entail?

Stephen Humphreys has argued that climate justice begins with the law ${ }^{4}$. Human rights law and commentaries by the respective treaty bodies are clear about identifying rights-holders, duty-bearers and obligations. Climate justice means to comply with the rights standards already agreed upon even if climatic impacts imply more far-reaching and costly implementation obligations than expected when fundamental human rights treaties were adopted and ratified.

As it stands today, however, the human rights regime is not set to sufficiently address situations of climate injustice, even more so as climate-related challenges exacerbate already existing situations of injustice. ${ }^{5}$ There are various debates on how human rights could further evolve to appropriately protect rights-holders that are affected by climate change and climate- 
related activities. Important examples for these debates could be observed in the run-up to the 2015 Paris Conference of the Parties (COP). By the end of 2014, the Special Procedures mandate-holders of the Human Rights Council, among others, the Special Rapporteur on the Human Right to Safe Drinking Water, the Special Rapporteur on Extreme Poverty and Human Rights, and the Special Rapporteur on the Rights of Indigenous Peoples, sent a letter to the State Parties of the United Nations Framework Convention on Climate Change (UNFCCC) urging them to include human rights in the new climate agreement. ${ }^{6}$ In the beginning of 2015, a group of 18 countries launched the 'Geneva Pledge for Human Rights in Climate Action' emphasizing the human rights implications of climate change and committing themselves to observing rights standards in climate-related action. ${ }^{7}$ During the Paris negotiations, the academic Global Network for the Study of Human Rights and the Environment adopted a 'Draft Declaration on Human Rights and Climate Change'. Its first principle declares that "Human rights and a profound commitment to climate justice are interdependent and indivisible". ${ }^{8}$ Also in the course of the negotiations, an inter-constituency alliance of non-state organizations (NGOs) persuaded states to institutionalize human rights in the climate agreement. This alliance comprised, among others, women and gender NGOs, youth NGOs as well as indigenous peoples' organizations. The Paris Agreement adopted on 12 December 2015 now acknowledges in its preamble that state parties should:

(...) when taking action to address climate change, respect, promote and consider their respective obligations on human rights, the right to health, the rights of indigenous peoples, local communities, migrants, children, persons with disabilities and people in vulnerable situations and the right to development, as well as gender equality, empowerment of women and intergenerational equity. ${ }^{9}$

These preambulatory clauses ${ }^{10}$ underline the close link between climate change, climaterelevant action, human rights and inter-generational justice. In this article, I want to delve deeper into understanding this link and the relationship between climate justice and human rights. I argue that an international human right to a clean and healthy environment is an important and comprehensive way to diminish climate injustice, understood as inter-national, inter-generational and intra-societal injustice, and therefore, it needs to be further developed.

Human rights can be defined as principled ideas of protecting human beings and providing them with all necessary elements for a life in dignity. In this sense, they define the relationship between a state and its citizens but increasingly also regulate the behavior of private businesses and other non-state actors. ${ }^{11}$ Human rights can be understood as a 
normative concept (prescribing how this relationship should be) but also as an empirical concept (with concrete implementation measures pertinent to specific human rights treaties). Moreover, human rights can bridge the gap between normative climate justice claims and empirical climate justice practices ${ }^{12}$. Systematically analyzing claims brought forward in the normative climate justice scholarship against concrete developments in human rights law and policy helps to gain a better understanding of how climate injustice can be diminished through concrete human activities. These developments comprise procedural rights in climate policies to diminish intra-societal injustice, extraterritorial state obligations (ETOs) to diminish international injustice and an international human right to a healthy environment. The latter is the most encompassing one, which would help to alleviate intra-societal, inter-national but also inter-generational injustice, and thus needs to be further institutionalized. It can be considered as emerging international law; it is anchored in several regional rights instruments and national constitutions but not yet fully institutionalized at the international level yet.

This article shall help to grasp the linkages between scholarship on climate justice and policy development in the area of human rights. Its aim is to demonstrate that further advancing procedural and substantive human rights obligations and corresponding enforcement mechanisms constitutes an important way of developing just climate practices. Bringing these often disconnected debates from Law and Political Theory together is a fruitful endeavor for International Relations (IR) scholars interested in climate change, human rights, or the institutional interaction between both. By systematically analyzing the normative literature on climate justice I suggest an analytical framework that can be useful in IR to evaluate institutional and policy developments against claims formulated by Political Theorists and Philosophers on how to diminish climate injustices.

This article is structured in the following way. First, I will disentangle the relationship between human rights and climate change. Second, I will systematize the literature on climate justice along three dimensions, inter-national, intra-societal and inter-generational injustice. In a third step, I will introduce developments on ETOs, procedural rights and an emerging human right to a healthy environment, and I will link these to the considerations on climate justice. Fourth, I will ask: What are the advantages and disadvantages of a human rights-based approach to climate justice? Finally, I will conclude by stating that strengthening further human rights developments, especially with a view to establishing a human right to a health environment, can make an important contribution to achieving more climate justice. 


\section{The Relationship between Climate Change and Human Rights}

The relationship between human rights and climate change is two-fold. One the one hand, the consequences of climate change have adverse effects on the enjoyment of human rights. And on the other hand, climate policies can lead to rights infringements of local communities, in particular indigenous peoples.

In the face of climate change, all three dimensions of human rights, (1) civil and political rights, (2) economic, social and cultural rights but also (3) collective rights can be at risk. Climate impacts, including heat waves, floods, storms, droughts and exceptional weather events can - in extreme cases - threaten civil and political rights, like the right to life. It is bindingly anchored in the International Covenant on Civil and Political Rights (ICCPR, 1966) and the Convention on the Rights of the Child (CRC, 1989). Sea level rise, temperature increase and changes in precipitation can also negatively affect the right to food, the right to water, the right to health and the right to adequate housing. ${ }^{13}$ All of these social rights are part of the International Covenant on Economic, Social and Cultural Rights (ICESCR, 1966). At the same time, they are also anchored in several core treaties of the UN Human Rights System, such as the 1979 Convention on the Elimination of All Forms of Discrimination against Women (CEDAW), the 1989 CRC or the 2006 Convention on the Rights of Persons with Disabilities (CRPD). Cultural rights are also affected by the implications of climate change. Human rights arguments in this area are raised to strengthen international cooperation for adaptation and mitigation programs to protect world heritage from changed weather conditions, temperature increases, floods, storms and droughts. ${ }^{14}$

The implications of climate change also affect collective rights, such as the right to selfdetermination. It is anchored in the ICESCR and the ICCPR, and reveals that peoples should be free to determine their political status but also their economic, social and cultural development. The right to self-determination can be threatened by rising sea levels and extreme weather events endangering the territorial existence of low-lying island states. It can also be at risk if indigenous peoples lose their traditional habitat as source of subsistence. When human beings have to abandon their state territory, their legal status and protection in the international system is unsettled. ${ }^{15}$

Moreover, climate impacts adversely affect the collective right to a healthy environment. Such a right is not yet bindingly anchored in the international human rights system of the UN. Nevertheless, it has found entrance into regional conventions, such as the 1981 African Charter on Human and Peoples 'Rights, the 2003 Protocol to the African Charter on Human 
and Peoples' Rights on the Rights of Women in Africa, the 2004 Arab Charter on Human Rights or the 1988 Additional Protocol to the American Convention on Human Rights. Thus, it can be considered to be a binding human right in several world regions. In addition to this, we can find judisprudence generated by different regional courts. The European Court of Human Rights, for instance, has made several rulings in favor of complainants in relation to environmental risks and pollution. It has also applied international environmental law principles and made reference to the decisions of other regional courts. In addition to that, there is a global trend to adopt environmental rights into national or federal constitutions. ${ }^{16}$

Table one summarizes the adverse effects of climate change on human rights. 
Table 1: The Adverse Effects of Climate Change on the Enjoyment of Human Rights ${ }^{17}$

\begin{tabular}{|c|c|c|c|}
\hline Climate Impact & Human Impact & Rights Affected & Regions Concerned \\
\hline $\begin{array}{l}\text { Sea Level Rise } \\
\text { - Flooding } \\
\text { - Sea surges } \\
\text { - Erosion } \\
\text { - Salination of land } \\
\text { and water }\end{array}$ & $\begin{array}{l}\text { - Loss of land } \\
\text { - } \\
\text { - Lack of clean water, } \\
\text { disease } \\
\text { - Damage to coastal } \\
\text { infrastructure, } \\
\text { homes and property } \\
\text { - Loss of agricultural } \\
\text { lands } \\
\text { - Threat to tourism, } \\
\text { lost beaches }\end{array}$ & $\begin{array}{ll}\text { - } & \text { Life (ICCPR, 6) } \\
\text { - } & \text { Self-determination } \\
& \text { (ICCPR, ICESCR, 1) } \\
\text { - } & \text { Health (ICESCR, 12) } \\
\text { - } & \text { Water (ICESCR 11,12) } \\
\text { - } & \text { Means of subsistence } \\
& \text { (ICESCR, 11) } \\
\text { - } & \text { Adequate housing } \\
& \text { (ICESCR, 11) } \\
\text { - } & \text { Culture (ICCPR, 27) } \\
\text { - } & \text { Property (UDHR, 17) }\end{array}$ & $\begin{array}{l}\text { Coastal (Low-lying) Areas } \\
\text { Low-lying Island States } \\
\text { Arctic Region }\end{array}$ \\
\hline $\begin{array}{l}\text { Temperature Increase } \\
\text { - Change in disease } \\
\text { vectors } \\
\text { - Coral bleaching } \\
\text { - Impact on fisheries } \\
\text { - Impact on agriculture }\end{array}$ & $\begin{array}{l}\text { - Spread of disease } \\
\text { - Change in fisheries } \\
\text { - Change in } \\
\text { agriculture } \\
\text { - Lost diversity } \\
\text { - Threat to tourism }\end{array}$ & $\begin{array}{ll}\text { - } & \text { Life (ICCPR, 6) } \\
\text { - } & \text { Health (ICESCR, 12) } \\
\text { - } & \text { Means of subsistence } \\
& \text { (ICESCR, 11) } \\
\text { - } & \text { Adequate standard of } \\
& \text { living, food (ICESCR, } \\
& \text { 11) }\end{array}$ & $\begin{array}{l}\text { Sub-Saharan Africa } \\
\text { Northern Africa } \\
\text { South-Asia } \\
\text { Latin America } \\
\text { Middle East }\end{array}$ \\
\hline $\begin{array}{l}\text { Extreme Weather } \\
\text { Events } \\
\text { - Higher intensity } \\
\text { storms } \\
\text { - Sea surges }\end{array}$ & 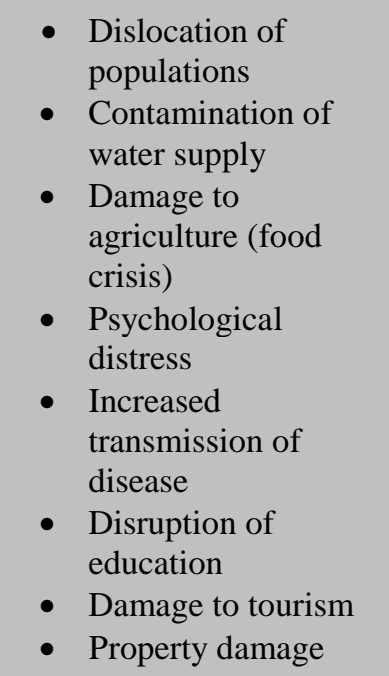 & $\begin{array}{ll}\text { - } & \text { Life (ICCPR, 6) } \\
\text { - } & \text { Health (ICESCR, 12) } \\
\text { - } & \text { Water (ICESCR, 11,12) } \\
\text { - } & \text { Means of subsistence } \\
\text { (ICESCR, 11) } \\
\text { - } & \text { Adequate standard of } \\
& \text { living (ICESCR, 11) } \\
\text { - } & \text { Adequate housing } \\
\text { (ICESCR, 11) } \\
\text { - } \\
\text { Education (ICESCR, } \\
\text { 13) }\end{array}$ & $\begin{array}{l}\text { South-East Asia } \\
\text { South Asia } \\
\text { Caribbean } \\
\text { Coastal Zones } \\
\text { Island States }\end{array}$ \\
\hline $\begin{array}{l}\text { Changes in } \\
\text { Precipitation } \\
\text { - Change in disease } \\
\text { vectors } \\
\text { - Erosion }\end{array}$ & $\begin{array}{l}\text { - Outbreak of disease } \\
\text { - Depletion of } \\
\text { agricultural soils }\end{array}$ & $\begin{array}{ll}- & \text { Life (ICCPR, 6) } \\
- & \text { Health (ICESCR, 12) } \\
\text { - } & \text { Means of subsistence } \\
& (\text { ICESCR, 11) }\end{array}$ & $\begin{array}{l}\text { Sub-Saharan Africa } \\
\text { South-East Asia } \\
\text { South Asia } \\
\text { Latin America }\end{array}$ \\
\hline
\end{tabular}

Based on data from: Marcos A. Orellana and Alyssa Johl, Climate Change and Human Rights: A Primer, (Washington: The Center for International Environmental Law, 2013) and supplemented with data from: OHCHR, Report. 
On the other hand, there are empirical studies demonstrating that the implementation of climate policies can also lead to severe human rights violations. This concerns mitigation measures, such as Reducing Emissions from Deforestation and Forest Degradation (REDD+) programs, Clean Development Mechanism (CDM) projects $^{18}$ and Green Economy (GE) strategies $^{19}$. It has been highlighted that in particular the transition process to altering energy patterns and a low-carbon economy can lead to human rights violations of local communities, indigenous peoples and (agro)-pastoral groups. ${ }^{20}$

Rights infringements pertinent to climate policy implementation often occur in the context of conflicts around property, land and resources. This means that in very extreme cases, violations to the right to life have been reported, particularly when violent relocations were undertaken. ${ }^{21}$ Furthermore, the right to property specified in Article 17 of the Universal Declaration of Human Rights (UDHR), and the right to development, stipulated in the Declaration on the Right to Development, are often neglected. Similarly affected is the right to self-determination and the right to subsistence as well as related social rights to adequate housing, to food, to water and to health (ICESCR). Thus, one can conclude by stating that human rights are at risk due to severe climate impacts and can be infringed with climate policy implementation.

\section{Dimensions of Climate Injustice}

There is a bulk of literature on climate justice, which is characterized by conceptual uncertainty. Despite this conceptual vagueness, considerations of climate justice have a few common denominators. They, first, stipulate a relational understanding of justice, i.e. the cognition that justice needs to be achieved between different actors. Therefore, it is relevant to establish the recipients (and burden-bearers) of justice and to establish which entities, i.e. individuals, groups, or countries, can raise claims against others. ${ }^{22}$ Second, there is the perception that climate change consequences exacerbate already existing inequalities. ${ }^{23}$ Environmental challenges can intensify economic and social disparities that might have their root causes elsewhere. Third, injustice in the context of climate change pertains to a situation, in which those who are the least responsible for greenhouse gas emissions are the ones that are most affected and most vulnerable to climate change consequences but have the fewest resources to adapt. ${ }^{24}$

In this section, I aim at systematizing the literature on climate justice along several characterizing features, including recipients, burden-bearers, temporal aspects and normative 
claims. Whereas some authors highlight justice concerns between states, i.e. inter-national injustice, others point to injustice between social groups, i.e. intra-societal injustice, or to an evolving injustice between today's and future generations, i.e. inter-generational injustice ${ }^{25}$. Deriving from these varying understandings, respective normative claims to enhancing climate justice also differ considerably.

Inter-national injustice emphasizes the historically grown relationship between developing and developed states ${ }^{26}$. The main concern is that developed countries have extensively utilized carbon-intensive industries to foster growth and developing countries (and emerging economies) shall not be able to do the same in the future. ${ }^{27}$ Many developing countries are, in addition to that, confronted with the consequences of climate change most severely by facing extreme weather events, increasing floods and intensified droughts. Hence, there is an imbalance between the contribution to climate change (by developed states), harm resulting from that and lacking resources to adapt (of developing states). This dimension of injustice is historically grown; it has its roots in colonial times, has been reinforced with globalization processes and is reflected in current institutions. ${ }^{28}$ Normative claims in inter-national injustice debates are that greenhouse gas emissions have to be reduced, adaptation and mitigation costs have to be more equally distributed and should relate to historic emission responsibilities (e.g. the polluter-pays-principle), energy and other consumption patterns need to alter, and fair institutions need to be created. ${ }^{29}$ Some of these claims are also reflected in the "common but differentiated responsibilities" approach put forward in the 1992 UNFCCC.

Harris, Chow and Karlsson, however, suggests to "[...] open up the traditionally closed box of "the state", [to] see that the real divide is not so much between developed and developing states as it is between affluent and poor people". ${ }^{30}$ Such intra-societal injustice concerns refer to the relationship among different groups between or within societies. Particular social groups are unequally exposed to the impacts of climate change to which they have contributed little. Environmental inequality "[...] reinforces and, at the same time reflects, other forms of hierarchy and exploitation along lines of class, race and gender" and may lead to situations of "double-discrimination". ${ }^{31}$ A report by the UN Human Rights Council identified women, children and indigenous peoples - but also the elderly and persons with disabilities - in developing countries to be particularly vulnerable to such challenges. ${ }^{32}$ Questions of social injustices have also been taken up by climate justice movements. Concrete demands in this respect do not only refer to equity but also to participation on the basis of comprehensive information, access to judicial remedies and compensation. ${ }^{33}$ Increasingly, claims for 
procedural justice and rights are also brought forward in the context of climate policy implementation. In 2010, under pressure of the climate justice movement, procedural rights were institutionalized for the implementation of REDD+ programs at the COP in Cancun. ${ }^{34}$

Finally, inter-generational justice pertains to the relationship between previous, current and future generations. Past and contemporary lifestyles, marked by the consumption of fossil fuels and high greenhouse gas emissions, have led to injustice toward future generations who might not be able to enjoy a clean and healthy environment. ${ }^{35}$ The current generation of decision-makers needs to be held accountable for not imposing risks on future generations who are not responsible for greenhouse gas emissions. Demands in this respect comprise the establishment of environmental rights $^{36}$, energy rights $^{37}$ but also rights-protecting institutions. $^{38}$ The idea behind such considerations is to introduce constitutional environmental human rights that oblige today's representatives to adopt policies that take the interests of future generations into account fostering ways of indirect (and inter-generational) democratic representation. ${ }^{39}$

All of these dimensions of injustice can also overlap, which means that future generations of certain societal groups in developing countries will be particularly exposed to these forms of injustice. Table two summarizes the dimensions of climate injustice. 


\begin{tabular}{|c|c|c|c|}
\hline & Inter-national Injustice & Intra-societal Injustice & $\begin{array}{l}\text { Inter-generational } \\
\text { Injustice }\end{array}$ \\
\hline $\begin{array}{l}\text { Character } \\
\text { of injustice }\end{array}$ & $\begin{array}{l}\text { Imbalance between } \\
\text { states' } \\
\text { responsibility and harm } \\
\text { as well as resources to } \\
\text { adapt }\end{array}$ & $\begin{array}{l}\text { Imbalance between } \\
\text { societal groups' } \\
\text { responsibility and harm } \\
\text { as well as resources to } \\
\text { adapt }\end{array}$ & $\begin{array}{l}\text { Imbalance between } \\
\text { past/current/future } \\
\text { generations' } \\
\text { responsibility and harm } \\
\text { as well as resources to } \\
\text { adapt }\end{array}$ \\
\hline Recipients & Developing states & $\begin{array}{l}\text { Societal groups, } \\
\text { communities, individuals }\end{array}$ & Future generations \\
\hline $\begin{array}{l}\text { Burden- } \\
\text { bearers }\end{array}$ & Developed states & $\begin{array}{l}\text { Capable states, } \\
\text { international community }\end{array}$ & $\begin{array}{l}\text { Capable states, } \\
\text { international community }\end{array}$ \\
\hline $\begin{array}{l}\text { Time } \\
\text { range }\end{array}$ & $\begin{array}{l}\text { Historically grown } \\
\text { Immediately }\end{array}$ & $\begin{array}{l}\text { Historically grown } \\
\text { Immediately }\end{array}$ & $\begin{array}{l}\text { Historically grown } \\
\text { Immediately } \\
\text { In the future }\end{array}$ \\
\hline Claims & $\begin{array}{l}\text { Fair distribution of } \\
\text { adaptation and mitigation } \\
\text { costs, just institutions, } \\
\text { compensation, reduction } \\
\text { of greenhouse gas } \\
\text { emissions }\end{array}$ & $\begin{array}{l}\text { Participation, } \\
\text { information, } \\
\text { transparency, access to } \\
\text { judicial recourse } \\
\text { procedures }\end{array}$ & $\begin{array}{l}\text { Transition to altering } \\
\text { energy and consumption } \\
\text { patterns and to a low- } \\
\text { carbon, sustainable } \\
\text { economy, codification of } \\
\text { environmental rights }\end{array}$ \\
\hline
\end{tabular}

Source: Own compilation on the basis of the literature cited.

\section{Linking Climate Justice and Human Rights Debates}

In the following section, I aim to link normative claims stipulated in the climate justice literature with concrete developments in human rights debates and practices.

\section{Extraterritorial State Obligations}

Rights obligations beyond borders have been intensively discussed in human rights scholarship, particularly after the introduction of the 2011 Maastricht Principles on Extraterritorial State Obligations (ETOs). In the literature, ETOs are discussed as "transboundary" or "transnational obligations". 40 They can be grasped as an obligation to international cooperation for realizing economic, social and cultural rights. ${ }^{41}$ This obligation is derived from several provisions of the UN Charter, the UDHR, the ICESCR but also of more recent treaties like the CRC. ${ }^{42}$ Article two of the ICESCR, for instance, states that: 
Each State Party to the present Covenant undertakes to take steps, individually and through international assistance and co-operation, especially economic and technical, to the maximum of its available resources, with a view to achieving progressively the full realization of the rights recognized in the present Covenant $[\ldots] .{ }^{43}$

This implies that member states are not only responsible for rights realization on their own state territory. In case they dispose of respective resources, they also assume responsibility for engaging into cooperative activities to progressively help implementing economic, social and cultural rights beyond their own territory. Next to territorial duties a state engages in when legally accepting a treaty, it also takes over extraterritorial obligations for the citizens of another state.

The meaning of ETOs becomes increasingly important in the context of progressing denationalization and global challenges. In one of his reports, the UN Special Rapporteur on Human Rights and the Environment, clearly states that the obligation to international cooperation is particularly relevant with regard to "[...] global environmental threats to human rights, such as climate change". ${ }^{44}$ Moreover, the Maastricht Principles underscore that states have an obligation to avoid extraterritorial harm which is due to activities or omissions of other states or even non-state actors, such as private companies. ETOs, for instance, were clearly stated in the petition issued by Greenpeace South Asia with other NGOs requesting an investigation of the responsibility of major fossil fuel companies for human rights violations resulting from the impact of climate change in the Philippines. These so-called "carbon majors" include Chevron, Exxon, BP and Shell, among others. The Commission on Human Rights of the Philippines reacted to this petition and launched a first-ever investigation into the responsibility of these companies for the drastic climate-related rights impacts on its population in 2015. Public hearings will take place in this ground-breaking case in 2017. The petition clearly states that:

"[...] extraterritoriality is not a bar to the Commission's exercise of authority, considering the transboundary and global nature of climate change and other environmental problems and the associated human rights implications." 45

ETOs entail the obligation to cooperate in order to realize economic, social and cultural rights even in the face of a changing climate. ${ }^{46}$ This interpretation implies that there is a requirement to assist developing countries to bear the costs of adaptation and mitigation policies. ${ }^{47}$ Thus, the concrete implementation measures in human rights treaties can be viewed as minimum standards that need to be achieved through adaptation and mitigation measures. The loss and 
damage article of the 2013 Warsaw Agreement calls for cooperation and cost-sharing in building the resilience of communities and ecosystems, including risk assessment and management, as well as non-economic losses. Here again human rights serve as a guidepost all cooperative action must be implemented with a view to protect basic human rights standards.

Hence, conforming states would foster inter-national justice by providing assistance to those states that lack resources to shoulder costly action to respect, protect and fulfill human rights in the context of climate-related challenges. Even more so, states and international organizations (IOs) would further intra-societal justice by assisting those community members of a society that are most affected in their enjoyment of human rights. A further principle emphasized in the Maastricht recommendations is the right to informed participation in any matters affecting citizen's rights. ${ }^{48}$ This is an important claim in intra-societal justice considerations and constitutes a fundamental human rights principle. The significance of participation is also reflected in current debates on procedural obligations in environmental policy-making.

\section{Procedural Rights}

Procedural rights are of particular importance in environmental law. They establish a link between the state and civil society by fostering transparency and participation in environmental decision-making. ${ }^{49}$ The most important procedural rights are the right to information, the right to participation and the right to justice, the latter usually meaning access to judicial and administrative recourse procedures. All of these rights are anchored in the 1948 UDHR and the 1966 ICCPR. Of far more influence in environmental matters, however, is the Convention on Access to Information, Public Participation in Decision-Making and Access to Justice in Environmental Matters, also known as the Aarhus Convention from 1998. Although it is only binding for ratifying states, it turned out to become the most relevant reference document when it comes to procedural rights in environmental matters. It has been drafted under strong NGO influence and focuses on establishing fair procedures for environmental regulations. ${ }^{50}$ Scholars accentuate the human rights character of the Aarhus Convention as it confers rights to individuals and not to states, it strengthens procedural mechanisms, and comprises non-compliance procedures that are very similar to those of the human rights monitoring bodies. Thus, it can be interpreted as a door-opener for a human right to a healthy environment. $^{51}$ 
Although, procedural rights are well-established in environmental law already and relevant case law from the European Court of Human Rights (ECtHR), the Inter-American Court of Human Rights and the Committee on Civil and Political Rights, they have recently gained increasing meaning in climate policy-making. During the COP 2010 in Mexico, for instance, procedural criteria for the realization of REDD+ programs were added to the Cancún Agreements. These safeguards encompass respect for the knowledge and rights of indigenous peoples and local communities as formulated in the 2007 UN Declaration on the Rights of Indigenous Peoples as well as effective participation of all affected people and free prior informed consent (FPIC) as anchored in the 1989 ILO Indigenous and Tribal Peoples Convention. A number of NGOs lobby for a revision of the modalities and procedures of the CDM in line with these rights. ${ }^{52}$ Infringements of local populations' and indigenous peoples' rights in relation to CDM project realization on the ground have continuously been a problem leading, for instance, to a landmark decision of Panama to withdraw the UN registration of its Barro Blanco hydroelectric dam project towards the end of $2016 .^{53}$

In the aftermath of COP 21 in Paris and during COP 22 in Marrakech procedural rights and institutional safeguards have also been discussed in relation to the newly established Sustainable Development Mechanism (SDM) ${ }^{54}$ Prior to the Marrakech negotiations in 2016, the OHCHR has made a submission to the UNFCCC process emphasizing "the need for robust social and environmental safeguards consistent with international human rights norms and standards" to guarantee that the SDM clearly achieves its objectives without contributing to rights violations. ${ }^{55}$ Besides their reflection in the UDHR, the ICCPR, the Rio Declaration and the Aarhus Convention, these procedural human rights obligations are further developed through the general comments of several treaty bodies and by the Special Rapporteurs as well as the ECtHR. ${ }^{56}$

Procedural rights can strengthen adaptation policies through the inclusion of valuable local knowledge and participation in decision-making. Mitigation action is much more likely to be accepted if it is developed in line with FPIC and in a transparent and participatory way. Previously, we have seen a number of mitigation policies becoming unsustainable, such as Barro Blanco introduced above, because the exclusion of affected population groups leads to contestation and conflict. Regarding loss and damage, the use of local knowledge, transparency and access to information are necessary for disaster preparedness, as well as risk assessment and management. 
The considerations made above show that procedural rights are particularly relevant when it comes to climate policy implementation. Even though there is empirical evidence that safeguards maybe difficult to adapt to local contexts or are not always carried out properly ${ }^{57}$, they have the potential to diminish intra-societal injustices. by providing information, ensuring transparency, including individuals and communities into environmental decisionmaking, granting access to the judiciary and administration and thus, enhancing participation opportunities.

\section{A Human Right to a Healthy Environment}

Although there is no substantial universal human right for the protection of the environment yet, its development is underway. ${ }^{58}$ The human rights treaty bodies have in several commentaries recognized the link between a healthy environment and the rights to life, adequate housing, food, water and health. ${ }^{59}$ Some scholars have made concrete suggestions on how a right to a healthy environment could be formulated. ${ }^{60}$ Others point to the fact that it can be derived from other substantive rights affected in the context of environmental challenges. Regional bodies including the European Committee on Social Rights (ECSR), the IACHR and the African Commission on Human and Peoples' Rights (ACHPR) have confirmed that environmental challenges can lead to infringements of economic, social and cultural rights like the right to health, water and food. ${ }^{61}$ There are also several cases, in which the ECtHR has already enforced social rights with respect to environmental matters and demanded compensation even by private polluters. ${ }^{62}$ Other indicators pointing to further developments in this respect are the establishment of environmental rights in regional human rights instruments and a large number of national constitutions. ${ }^{63}$ Some scholars argue that due to the existence and application at the regional and national level, a right to a healthy environment is already consolidated.

The UN Special Rapporteur on Human Rights and the Environment, John Knox, calls upon states to accept procedural but also substantive human rights obligations relating to the environment as existing or emerging international law. ${ }^{64}$ One important argument underlining this emergence is closely related with ETOs and the duty to international cooperation stipulated in the ICESCR. Knox highlights the significance of cooperation in the face of climate change: "The most feasible basis for extending current environmental human rights jurisprudence to climate change is the duty to cooperate". ${ }^{65}$ Hence, one can understand the ICESCR as the basis for further developments in environmental human rights law and the 
duty to cooperate anchored therein can pave the way to an emerging international human right to a healthy environment. In November 2017, Knox has held consultations on Draft Guidelines on Human Rights and the Environment. Article 9 of these guidelines outlines that every state has an obligation to establish and enforce a normative framework for a clean, healthy and sustainable environment, including:

"effective legal and institutional mechanisms to regulate the activities of public and private actors in order to prevent, reduce and remedy environmental harm that interferes with the full enjoyment of human rights." 66

By defining procedural and substantive obligation in relation to preventing, reducing, and remedying environmental harm that interferes with the enjoyment of human rights, Knox has made an important further step towards an international environmental human right through legal analysis and emerging practice.

With the establishment of a human right to a healthy environment, states could make use of the United Nations human rights system to regularly monitor whether adequate actions as well as appropriate cooperation programs with respect to adaptation, mitigation and loss and damage are in place. The Universal Periodic Review Mechanism, the Special Procedures (consisting of thematic and country-specific mandates) and the treaty body (a new one would be created with a new binding human rights treaty) would help states to engage into a dialogue, make concrete recommendations, and strengthen capacities and technical assistance, in order to protect human rights in the face of climate impacts and in order for climate policies to be implemented in consistence with human rights standards.

A human right to a healthy environment is oriented towards protecting individuals and communities from adverse climate change impacts today and in the future. By emphasizing the duty to international cooperation, it shows strong parallels with the debate on ETOs and hence, bears the potential to advance inter-national justice (by providing assistance) and intra-societal justice (by fulfilling the rights of societal groups). An environmental human right would also take the interests of future generations into account by fostering cooperative activities to guarantee clean air, water and land. This means this emerging norm has the potential to contribute to inter-generational justice - reflecting the demand for protecting future generations on the basis of equity and common but differentiated responsibilities stipulated in the 1992 UNFCCC. Thus, a human right to a healthy environment can be considered the most encompassing step that would contribute to achieving more international, intra-societal and inter-generational justice. 


\section{Advantages and Disadvantages of a Human Rights-Based Approach to Climate Justice}

What are the advantages and disadvantages of a human rights-based approach to climate justice - and of strengthening the human rights regime, i.e. ETOs, procedural rights and a human right to a healthy environment, in the context of contemporary climate challenges? Let us begin with carving out the advantages. First, human rights can bridge the divide between normative justice claims and empirical climate practices, i.e. human activities to diminish climate injustice. Human rights constitute a normative concept, but at the same time, rights instruments also entail concrete empirical implementation measures. Since the adoption of the UDHR, recognition for equal and inalienable rights has been understood as building the foundation for justice. ${ }^{67}$ Today, scholars increasingly link already existing human rights obligations to climate change ${ }^{68}$ and climate justice. ${ }^{69}$ Knox reminded negotiating state parties in Paris that: "States' human rights obligations also encompass climate change," and that "[...] they must ensure that all of their actions comply with their human rights obligations. That includes their actions relating to climate change" ${ }^{70}$ In fact, there is no single state government in the world anymore that has not committed to at least one of the UN core conventions on human rights. ${ }^{71}$ And these entail concrete implementation measures, including ETOs in conventions containing economic, social and cultural rights, which can serve as a guidepost for just climate practices. This means realizing existing human rights, closing implementation gaps and further developing the human rights system can be understood as a concrete climate practice diminishing inter-national, intra-societal and inter-generational injustice.

Second, the language of human rights is strong; it emphasizes the need for immediate political action and cannot be easily ignored in contemporary politics. ${ }^{72}$ State actors from liberal and democratic countries usually shy away from neglecting human rights because they consider them to be an integral part of their identity. ${ }^{73}$ Human rights models, such as the Boomerang Pattern or the Spiral Model of Human Rights Change, emphasize how human rights norms become adopted and internalized if pressure from above, i.e. by transnational human rights networks, and from below, i.e. by domestic opposition groups, is exerted. ${ }^{74}$ Thus, embedded in a human rights discourse, climate change is framed a matter of immediate human urgency as opposed to a technocratic matter of interstate negotiations. It emphasizes a "pressingly relevant" need for action employing the "muscular language of human rights"75 and it can unleash argumentative, persuasive or pressure mechanisms exerted on state actors to change 
climate policies and make them more human-centered. The employment of pressure and persuasion mechanisms becomes more likely as recently also some of the big human rights NGOs, Human Rights Watch and Amnesty International, have taken up the issue of climate change and become particularly active in this regard. ${ }^{76}$

Third, by employing a human rights-based approach to climate justice, the situation of individual and collective rights-holders becomes central (as opposed to tedious state negotiations). Human rights define the relationship between a state government and its citizens. ${ }^{77}$ Rights norms have a hybrid function; they constitute inter-state regulations, but also define norms relevant within societies, for respective rights-holders. This focus on the rights-holders is particularly important if one takes the trans-boundary character of climate change and its unequal implications on vulnerable groups and individuals into consideration. Women, children, elderly, disabled or indigenous peoples and standards for their protection move to the center of attention and policy solutions - as opposed to political negotiations.

Fourth, a human rights perspective can be fruitful for assigning obligations. In many cases, these can be derived from the required implementation measures of already existing human rights treaties state parties have committed to. Obligations do not only exist between a ratifying state government and its citizens but also between a ratifying capable state government and the citizens of other, less capable countries. This duty to international cooperation can be found in the UN Charter, the UDHR and the ICESCR. ${ }^{78}$ Obligations to international cooperation are also stipulated in targeted treaties, like the CRC, and other conventions containing economic, social and cultural rights. The 2011 Maastricht Principles constitute a recent attempt to strengthen extraterritorial obligations of states and IOs as well as state responsibility for the acts and omissions of non-state actors and transnational corporations. $^{79}$

Fifth, human rights and the obligation to international cooperation as reaffirmed in the Maastricht Principles can build the constitutive basis for climate policy programs. Procedural safeguards can guide the design of climate policies, like REDD+ programs, CDM or SDM projects as well as green economy policies. This means a "human rights-based approach to climate change negotiations, policies and measures" $" 80$ can help vulnerable states in cooperating with capable states and IOs to face the consequences of climate change, to design just climate policies and to implement the human rights of their citizens at the same time.

Finally, a human rights framework can build an analytical umbrella around many relevant issues pertaining to climate change. It accommodates various aspects of human security, of 
migration and the protection of climate refugees, and - by fostering economic, social and cultural rights - it frequently enters common ground with development issues. Hence, a broad-ranging human rights framework embraces a variety of issues relating to climate justice (that cannot be merely treated in isolation from each other) with a view to protecting affected vulnerable groups and individuals.

The main disadvantages or challenges pertaining to a human rights-based approach to climate justice are, first of all, enforcement and compliance. Although some human rights conventions, such as the CRC or CEDAW, have been nearly universally ratified, key gaps in implementation prevail. In IR scholarship on norms, this "compliance gap" ${ }^{81}$ has been grasped in conceptual differentiations between "prescriptive status" and "norm-consistent behavior". ${ }^{82}$ Progressive human rights realization of economic, social and cultural rights is a key challenge and the consequences of climate change exacerbate implementation challenges. The chronic under-fulfillment of human rights goals often lead to skepticism with respect to adopting a rights approach to climate justice. ${ }^{83}$

Second, scholars and practitioners have pointed to the impossibility of disentangling cause and effect when it comes to climate change implications on human rights. ${ }^{84}$ Anthropogenic climate change has mainly been caused in industrialized states, mostly by private companies, and has devastating effect among vulnerable societal groups in developing countries that often lack the resources to adapt. According to human rights treaties, the ratifying state governments are primarily responsible for respecting, protecting and promoting the rights of their citizens. This would mean that - in the first place - governments of developing states (who do not bear the main responsibility for climate change) have the obligation to secure their citizens' human rights. If they are lacking the capability to do so, the international community has the duty to cooperate. This complex constellation of cause and effect over time, however, as well as the involvement of public and private actors at various levels and in different world regions makes identifying duty-bearers and assigning (extraterritorial) obligations an ambiguous task ${ }^{85}$.

Third, there are concerns about potentially over-expanding the international human rights catalogue, which comes with the risk of devaluing it. ${ }^{86}$ Since 2008 , there have been six resolutions passed by the Human Rights Council on the relationship between climate change and human rights. The question is whether, next to non-binding resolutions and declarations, a new convention on the same level as the core UN human rights treaties can evolve (potentially embracing an international human right to a healthy environment). There could be 
strong arguments for rights concerns in the context of climate change to be covered under the ICESCR - and even adding another optional protocol to it can been regarded as a fairly ambitious endeavor. ${ }^{87}$ The skepticism around economic, social and cultural rights and even more so regarding collective rights will make the adoption and implementation of environmental human rights a difficult task.

Fourth, inter-generational aspects are difficult to work in practice by current decision-makers and have so far mostly been addressed by scholars in Political Theory and Philosophy. ${ }^{88}$ Although scholars argue that constitutionally guaranteeing a fundamental human right to a healthy environment today, would enable favorable conditions for rights protection in the future $^{89}$, several concerns remain. Who exactly can speak for future generations, how can they be represented and in which way can we assess their interests? ${ }^{90}$ Protecting the rights of future generations in a changing environment means to reshape current political systems and institutions ${ }^{91}$, which is quite an ambitious endeavor and often too far away from current political realities and agendas.

Fifth, there are ideological tensions between the human rights and the environmentalist movement. Whereas the human rights movement has an anthropocentric orientation, placing human beings in the center of decision-making, environmentalists rather follow an ecocentric approach, focusing on the entire ecosystem. This tension can lead to different priorities when it comes to the formulation of policy programs, specifically on issues like development, economic growth or population control, ${ }^{92}$ and can lead to a situation in which a human rights framework may lack the necessary support of environmental groups.

Finally, the human right to a healthy environment as a collective right is severely contested. Collective rights belong to the third dimension and are not bindingly anchored in the UN human rights edifice due to many states questioning their universality. Thus, environmental rights have found entrance in many national constitutions and some regional conventions but there is resistance regarding the establishment of an international human right. Although there is an intensive academic discourse encompassing normative claims for a right to ecological space $^{93}$, environmental rights ${ }^{94}$ or concrete formulations for a substantive human right for the protection of the environment ${ }^{95}$, its development in practice still is controversial.

An awareness of these arguments and counterarguments is important for taking a clear position in this debate. In this article, I argue in favor of strengthening procedural rights, extraterritorial state obligations and a human right to a healthy environment as relevant ways to diminish climate injustice. Let me briefly explain how I would reply to the disadvantages 
or counterarguments brought forward above. Enforcement and compliance deficits within the human rights system only partly relate to lacking political will and are very often caused by missing capacities, resources and expertise ${ }^{96}$. Thus, increased cooperation leads to better compliance, especially when it comes to economic, social and cultural rights that are mostly affected by climate change and climate politics. If the international community cooperates, we do not need to disentangle cause and effect in more detail than this was done within the UNFCCC (Annex I and non-Annex I countries) already. Moellendorf, for example, argues for an "ability to pay" account in climate change treaties signaling that this duty needs to be taken seriously and that countries have the right to sustainable development. ${ }^{97}$ This is exactly how the duty to cooperate in human rights treaties can be understood; those countries that have ratified and have the capacities to implement rights financially and technically support those countries that have ratified but lack capacities to implement.

There are many examples illustrating how ideological tensions between the human rights and environmentalist movement do not prevent NGOs or IOs to collaborate and take a hybrid approach rather than insisting on ecocentric or anthropocentric arguments. An interesting case is the inter-constituency alliance at COP 21 in Paris mentioned in the introduction of this article, in which environmental, human rights, youth, gender and indigenous peoples' groups worked together. Since Bonn 2017, the inter-constituency alliance has been renamed into 'coalition for rights' taking even more actors on board and it increasingly makes references to ecosystem integrity as a key principle, together with indigenous peoples rights, food security, public participation, gender equality and just transition, in implementing the Paris agreement. $^{98}$

Moreover, human rights have always been further developed in response to current challenges in the world. Thus, they are dynamic and not static. And even though we should not overexpand the human rights catalogue, we should also not hamper developments in response to serious threats. Probably the most significant example for this is the development of international human rights after World War II. Individual rights above the state and independent of nationality at that time were understood to be the foundation for freedom, peace and justice in the world. Facing the severe challenges of climate change today, we will most probably see the human rights evolving from individual civil and political rights to collective intergenerational environmental rights. 


\section{Conclusions}

In this article, I have tried to link considerations on climate justice with current human rights developments relating to climate change and climate policies. My aim was to show in which way rights developments and pertinent debates can be linked to the normative claims brought forward in considerations on climate justice. This analysis helps to develop a better understanding of the linkage between climate justice and human rights but also how concrete climate justice practices can be shaped through further human rights development and effective enforcement. I have argued that further developing a human right to a healthy environment would be the most encompassing step to address climate injustice.

The analysis reveals the following results: Procedural and substantive human rights obligations relating to climate change and climate policies are still evolving. Procedural rights have, for instance, been adopted as institutional safeguards for REDD+ programs in 2010 but their effectiveness in program implementation have not been comprehensively evaluated yet. Further developments in this respect, including safeguards for the CDM or the newly established SDM as well as for green economy policies can be expected. They have the potential to protect particularly vulnerable groups from the adverse effects of climate policies and hence, can advance intra-societal justice. As procedural rights have entered UNFCCC negotiations, prospects of their advancement are particularly high and we can expect further institutional developments in this respect in the short run.

ETOs have their origins in the UN Charter in 1945 and gained significant meaning with the adoption of the ICESCR in 1966. By strengthening the duty to international cooperation in the area of economic, social and cultural rights, ETOs bear the potential to foster inter-national justice. By assisting states to fulfill these rights for respective individuals and communities, they also further intra-societal justice. In the face of climatic challenges, ETOs will be advanced through the commentaries of the human rights treaty monitoring bodies, first and foremost the Committee on Economic, Social and Cultural Rights, but also through regional court decisions and case law. This is already relevant today and will receive further attention and changes in human rights soft law in the coming years.

An international human right to a healthy environment would be the most encompassing advancement in the global human rights edifice. It would not only promote inter-national and intra-societal but also inter-generational justice by entailing duties to preserve the environment, i.e. water, air and soil, for future generations. ${ }^{99}$ There are many sceptics pertinent to the emergence of such a collective human right to a healthy environment and I 
have discussed a number of counter-arguments above. In November 2017, John Knox has held consultations on draft guidelines on human rights and the environment including procedural and substantive state obligations. These guidelines can be understood as a further important step towards establishing an international human right to a healthy environment. Institutionalization processes of environmental human rights are further progressing and need to be supported to diminish climate injustice. It is important to note that in the face of a changing climate and demands for more climate justice, human rights are changing and developing - from individual civil and political rights to collective intergenerational rights.

The systematization of the climate justice literature presented above can also be used as an analytical framework for IR scholars interested in regime complexity ${ }^{100}$, institutional interaction and institutional interplay ${ }^{101}$ of climate change with other policy fields, such as human rights, but also development, economics and trade. In this way, climate justice scholarship can be usefully integrated into empirical studies in IR to evaluate institutional and policy developments against normative claims formulated by Political Theorists and Philosophers on how to diminish climate injustices. It has the potential to bring often disconnected debates together and to shape ideas on concrete climate justice practices in a number of policy fields. 


\section{Endnotes}

${ }^{1}$ Steven Humphreys, 'Climate Justice: The Claim of the Past', Journal of Human Rights and the Environment 5(0), 2014, pp. 134-148.

${ }^{2}$ Ludvig Beckman and Edward Page, 'Perspectives on justice, democracy and global climate change', Environmental Politics 17(4), 2008, pp. 527-535.

${ }^{3}$ Edward Page, Climate Change, Justice and Future Generations, (Cheltenham: Edward Elgar, 2006), p. 50.

${ }^{4}$ Humphreys, 'Climate Justice', pp. 141-147.

${ }^{5}$ Steve Vanderheiden, 'Justice in the Greenhouse: Climate Change and the Idea of Fairness', Social Philosophy Today 19, 2004, pp. 89-101.

6، A New Climate Agreement Must Include Human Rights Protections For All', OHCHR 2014, available at: http://www.ohchr.org/Documents/HRBodies/SP/SP_To_UNFCCC.pdf (accessed 28 February 2017).

7'Promoting the Geneva Pledge for Climate Action', Human Rights and Climate Change Working Group 2015, available at: http://climaterights.org/our-work/unfccc/geneva-pledge/ (accessed 28 February 2017).

'Draft Declaration on Human Rights and Climate Change', available at: http://gnhre.org/wpcontent/uploads/2015/11/GNHRE-draft-declaration1.pdf (accessed 28 February 2017).

'Paris Agreement: Adopted at the $21^{\text {st }}$ Conference of the Parties', UNFCCC 2015, available at: http://unfccc.int/files/essential_background/convention/application/pdf/english_paris_agreement.pdf (accessed 10 January 2017).

${ }^{10}$ The initial ambition of the inter-constituency alliance was to anchor human rights in article two of the operative part which defines the purpose of the Paris agreement. Although this could not be realized, the inter-constituency alliance still considers itself to have substantially contributed to including human rights in the final agreement, although only in the preambulatory clauses.

${ }^{11}$ Hans-Peter Schmitz and Kathryn Sikkink, 'International Human Rights', in Walter Carlsnaes, Thomas Risse, and Beth A. Simmons (eds) Handbook of International Relations (London: SAGE, 2013), p. 827.

${ }^{12}$ Practices are competent performances structuring world politics, giving meaning to international action and interaction by reproducing, changing and reinforcing action and interaction. Thus, climate justice practices can be understood as policy-specific every day activities to diminish climate injustice. Emmanuel Adler and Vincent Pouliot, 'International Practices', International Theory 3(1), 2011, pp. 1-36.

${ }^{13} \mathrm{OHCHR}$, Report of the Office of the United Nations High Commissioner for Human Rights on the Relationship between Climate Change and Human Rights, Office of the High Commissioner for Human Rights, 2009), p.13.

${ }^{14}$ Silvia Maus, 'Hand in Hand against Climate Change: Cultural Human Rights and the Protection of Cultural Heritage', Cambridge Review of International Affairs 27(4), 2014, pp. 699-716.

${ }^{15}$ OHCHR, Report, pp.14-15.

${ }^{16}$ James R. May and Erin Daly, Global Environmental Constitutionalism, (Cambridge: Cambridge University Press, 2014).

${ }^{17}$ Based on data from: Marcos A. Orellana and Alyssa Johl, Climate Change and Human Rights: A Primer, (Washington: The Center for International Environmental Law, 2013) and supplemented with data from: OHCHR, Report.

${ }^{18}$ Jeanette Schade and Wolfgang Obergassel, 'Human Rights and the Clean Development Mechanism', Cambridge Review of International Affairs 27(4), 2014, pp. 717-735.

${ }^{19}$ Human Rights Watch, There is No Time Left: Climate Change, Environmental Threats, and Human Rights in Turkana County, Kenya, (New York, Human Rights Watch, 2015). 
${ }^{20}$ Eve Bratman, 'Passive Revolution in the Green Economy: Activism and the Belo Monte Dam', International Environmental Agreements 15(1), 2015, pp. 61-77.

${ }^{21}$ Human Rights Watch, What Will Happen if Hunger Comes? Abuses Against the Indigenous Peoples of Ethiopia's Lower Omo Valley, (New York: Human Rights Watch, 2012).

${ }^{22}$ Beckman and Page, 'Perspectives on justice'.

${ }^{23}$ Humphreys, 'Climate Justice'.

${ }^{24}$ Karen Morrow, 'Climate Change and Human Rights: The Defining Dilemma of Our Times?', Journal of Human Rights and the Environment 1(2), 2010, p. 132.

${ }^{25}$ Or climate justice in relation to the non-human world. See: Clare Palmer, 'Does Nature Matter? The Place of the Nonhuman in the Ethics of Climate Change' in Denis G. Arnold (ed) The Ethics of Global Climate Change (Cambridge: Cambridge University Press, 2011), pp. 272-291.

${ }^{26}$ Henry Shue, Climate Justice: Vulnerability and Protection, (Oxford: Oxford University Press, 2014).

${ }^{27}$ Moellendorf, Darrel, The Moral Challenge of Dangerous Climate Change: Values, Poverty and Policy, (Cambridge: Cambridge University Press, 2014).

${ }^{28}$ Humphreys, 'Climate Justice', pp. 141-147.

${ }^{29}$ Richard P. Hiskes, The Human Right to a Green Future: Environmental Rights and Intergenerational Justice, (Cambridge: Cambridge University Press, 2009).

${ }^{30}$ Paul G. Harris, Alice S.Y. Chow and Rasmus Karlsson, 'China and Climate Justice: Moving beyond Statism', International Environmental Agreements 13(3), 2013, pp. 293-301.

${ }^{31}$ Peter Newell, 'Race, Class and the Global Politics of Environmental Inequality', Global Environmental Politics 5(3), 2005, p. 70 and p. 87.

${ }^{32}$ OHCHR, Report, pp. 15-18.

${ }^{33}$ These rights are anchored in the 1966 ICCPR and in the 1998 Aarhus Convention.

${ }^{34}$ 'The Cancun Agreements', available at: http://unfccc.int/resource/docs/2010/cop16/eng/07a01.pdf\#page=2 (accessed 10 January 2017).

${ }^{35}$ Richard P. Hiskes, 'The Right to a Green Future: Human Rights, Environmentalism and Intergenerational Justice' Human Rights Quarterly 27(4), 2005, pp. 1346-1364.

${ }^{36}$ Hiskes, 'The Right to a Green Future'.

${ }^{37}$ Simon Caney, 'Climate Change, Energy Rights and Equality' in Denis G. Arnold (ed) The Ethics of Global Climate Change (Cambridge: Cambridge University Press, 2011), pp. 77-103.

${ }^{38}$ Shue, Climate Justice.

${ }^{39}$ Beckman and Page, 'Perspectives on justice'.

${ }^{40}$ Sigrun Skogly, Beyond National Borders: States' Human Rights Obligations in International Cooperation (Antwerpen: Intersentia, 2006), p.5.

${ }^{41}$ Caroline Mair, The Maastricht Principles and Environmental Law (London: Foundation for International Environmental Law and Development, 2012), p. 3.

${ }^{42} \mathrm{de}$ Schutter, Olivier et al., 'Commentary to the Maastricht Principles on Extraterritorial Obligations of States in the Area of Economic, Social and Cultural Rights' Human Rights Quarterly 34(4), 2012, pp. 1091-1104.

${ }^{43}$ International Covenant on Economic, Social and Cultural Rights, available at: http://www.ohchr.org/EN/ProfessionalInterest/Pages/CESCR.aspx (accessed 10 January 2017), Art. 2.

${ }^{44}$ John Knox, Report of the Independent Expert on the Issue of Human Rights Obligations Relating to the Enjoyment of a Safe, Clean, Healthy and Sustainable Environment (Geneva: Human Rights Council, 2014), p. 18.

${ }^{45}$ 'The Climate Change and Human Rights Petition' available at: http://www.greenpeace.org/seasia/ph/press/releases/Worlds-largest-carbon-producers-ordered-to-respond-to- 
allegations-of-human-rights--abuses-from-climate-change/The-Climate-Change-and-Human-Rights-Petition/ (accessed 28 February 2017).

${ }^{46}$ Marc Limon, 'Human Rights and Climate Change: Constructing a Case for Political Action' Harvard Environmental Law Review 33(2), 2009, pp. 439-476.

${ }^{47}$ John Knox, 'Climate Change and Human Rights Law' Virginia Journal of International Law 50(1), 2009, p. 208.

${ }^{48}$ 'Maastricht Principles on Extraterritorial Obligations of States in the Area of Economic, Social and Cultural Rights' available at: http://www.ciel.org/wp-content/uploads/2015/05/Maastricht_ETO_Principles_21Oct11.pdf (accessed 10 January 2017).

${ }^{49}$ Aarti Gupta, 'Transparency Under Scrutiny: Information Disclosure in Global Environmental Governance' Global Environmental Politics 8(2), 2008, pp. 1-7.

${ }^{50}$ Gupta, 'Transparency Under Scrutiny', p. 3-4.

${ }^{51}$ Alan Boyle, 'Human Rights and the Environment: Where Next?' European Journal of International Law 23(3), 2012, pp. 622-626.

${ }^{52}$ Schade and Obergassel, 'Human Rights and the Clean Development Mechanism'.

${ }^{53}$ 'Press Statement - In landmark decision, Panama withdraws UN registration for Barro Blanco hydrodam project', Carbon Market Watch 2016, available at: http://carbonmarketwatch.org/press-statement-in-landmarkdecision-panama-withdraws-un-registration-for-barro-blanco-hydrodam-project/ (accessed 28 February).

${ }^{54}$ 'COP 22', Carbon Market Watch 2016, available at: http://carbonmarketwatch.org/category/climatenegotiations/cop22/ (accessed 28 February 2017).

${ }^{55} \mathrm{OHCHR}$, Comments and recommendations of OHCHR regarding the future UNFCC Sustainable Development Mechanism, (Geneva: OHCHR, 2016).

${ }^{56}$ Knox, Report of the Independent Expert, p. 9.

${ }^{57}$ Roe, Stephanie et al., Safeguards in REDD+ and Forest Carbon Standards: A Review of Social, Environmental and Procedural Standards and Application (Amsterdam, ClimateFocus, 2013).

${ }^{58}$ Stephen J. Turner, A Global Environmental Right (Abingdon: Routledge, 2014).

${ }^{59} \mathrm{OHCHR}$, Report, p 3.

${ }^{60}$ James W. Nickel, 'The Human Right to a Safe Environment: Philosophical Perspectives on Its Scope and Justification', Yale Journal of International Law 18 (1), 1993, pp. 281-295; Tim Hayward, Constitutional Environmental Rights, (Oxford: Oxford University Press, 2005).

${ }^{61}$ Knox, 'Climate Change and Human Rights Law', pp. 177-178.

${ }^{62}$ Stephen Humphreys, 'Climate Change and International Human Rights Law' in Rosemary Rayfuse and Shirley V. Scott (eds), International Law in the Era of Climate Change (Cheltenham: Edward Elgar, 2012), pp. $29-57$.

${ }^{63}$ David R. Boyd, The Environmental Rights Revolution: A Global Study of Constitutions, Human Rights, and the Environment (Vancouver: University of British Columbia Press, 2012).

${ }^{64}$ Knox, Report of the Independent Expert, p. 8.

${ }^{65}$ Knox, 'Climate Change and Human Rights Law', p. 212.

${ }^{66}$ John Knox, Draft Guidelines on Human Rights and the Environment (Geneva: Human Rights Council, 2017).

${ }^{67}$ 'Universal Declaration of Human Rights' available at: http://www.un.org/en/universal-declaration-humanrights/ (accessed 11 January 2017), preamble.

68،COP21: 'States' human rights obligations encompass climate change' - UN expert' available at: http://www.ohchr.org/EN/NewsEvents/Pages/DisplayNews.aspx?NewsID=16836\&LangID=E (accessed 21 July 2016).

${ }^{69}$ Humphreys, 'Climate Justice'.

${ }^{70}$ 'COP21: 'States' human rights obligations encompass climate change' - UN expert'.

${ }^{71}$ COP21: 'States' human rights obligations encompass climate change' - UN expert'. 


\footnotetext{
${ }^{72}$ Hiskes, The Human Right to a Green Future, p. 2.

${ }^{73}$ Thomas Risse, Stephen C. Ropp, and Kathryn Sikkink, The Power of Human Rights: International Norms and Domestic Change (Cambridge: Cambridge University Press, 1999), p. 23.

${ }^{74}$ Thomas Risse, Stephen C. Ropp, and Kathryn Sikkink (eds), The Persistent Power of Human Rights: From Commitment to Compliance. Cambridge: Cambridge University Press, 2013.

${ }^{75}$ Hiskes, The Human Right to a Green Future, pp. 3-5.

76،Joint Statement: Protection of Human Rights from Climate Change Requires Urgent Shift to 100\% Renewable Energy for All', available at: https://www.amnesty.org/en/documents/pol30/3033/2015/en (accessed 17 June 2016).

${ }^{77}$ Schmitz and Sikkink, 'International Human Rights', p. 827.

${ }^{78}$ de Schutter, Olivier et al., 'Commentary to the Maastricht Principles', pp. 1091-1104.

${ }^{79}$ 'Maastricht Principles on Extraterritorial Obligations of States'.

${ }^{80} \mathrm{OHCHR}$, Applying a Human Rights-Based Approach to Climate Change Negotiations, Policies and Measures (Geneva: OHCHR, 2010).
}

${ }^{81}$ Xinyuan Dai, 'The “Compliance Gap" and the Efficacy of International Human Rights Institutions' in Thomas Risse, Stephen Ropp, and Kathryn Sikkink (eds), The Persistent Power of Human Rights: From Commitment to Compliance (Cambridge: Cambridge University Press, 2013), p. 85.

${ }^{82}$ Risse, Ropp, and Sikkink, The Power of Human Rights, p. 29, p. 33.

${ }^{83}$ Kerri Woods, Human Rights and Environmental Sustainability (Cheltenham: Edward Elgar Press, 2010).

${ }^{84}$ Dudai, 'Climate Change and Human Rights Practice' Journal of Human Rights Practice 1(2), 2009, pp. 294307.

${ }^{85}$ On indirect or mediated responsibilities see also: Robin Attfield, 'Mediated Responsibilities, Global Warming and the Scope of Ethics' Journal of Social Philosophy 40(2), 2009, pp. 225-236.

${ }^{86}$ Philip Alston, 'Conjuring up New Human Rights: a Proposal for Quality Control' American Journal of International Law 78(3), 1984, pp. 607-621.

${ }^{87}$ Dudai, 'Climate Change and Human Rights Practice', p. 305.

${ }^{88}$ Hiskes, The Human Right to a Green Future.

${ }^{89}$ Tim Hayward, 'Human Rights Versus Emissions Rights: Climate Justice and the Equitable Distribution of Ecological Space' Ethics and International Affairs 21(4), 2007, pp. 431-450.

${ }^{90}$ Dudai, 'Climate Change and Human Rights Practice', p. 302.

${ }^{91}$ Beckman and Page, 'Perspectives on justice', p. 529; for a different perspective see also Kerri Woods, 'The rights of (future) humans qua humans' Journal of Human Rights 15(2), 2016, pp.291-306.

${ }^{92}$ Dudai, 'Climate Change and Human Rights Practice'.

${ }^{93}$ Hayward, 'Human Rights Versus Emissions Rights'.

${ }^{94}$ Hiskes, The Human Right to a Green Future.

${ }^{95}$ Turner, A Global Environmental Right.

${ }^{96}$ Risse, Ropp, and Sikkink, The Power of Human Rights.

${ }^{97}$ Moellendorf, The Moral Challenge of Climate Change, p.7.

${ }^{98}$ CIEL et al., 'Delivering on the Paris Promises: Combating Climate Change While Protecting Rights' available at: https://www.deliveringonparis.com/wp-content/uploads/2017/06/Delivering-On-Paris-Web.pdf (accessed 26 November 2017).

${ }^{99}$ Hiskes, The Human Right to a Green Future, p. 143.

${ }^{100}$ Kenneth W. Abbott, 'Strengthening the Transnational Regime Complex for Climate Change' Transnational Environmental Law 3(1), 2014, pp. 57-88; Eero Palmujoki, 'Fragmentation and Diversification of Climate Change Governance in International Society’ International Relations 27(2), 2013, pp. 180-201. 
${ }^{101}$ Thomas Gehring and Sebastian Oberthür, 'The Causal Mechanisms of Interaction between International Institutions' European Journal of International Relations 15(1), 2009, pp. 125-156. 